\title{
Makna Ruang Pangrampak dalam Arsitektur Toraja
}

\author{
Lexsi Yosua Masseleng*, Muh. Mochsen Sir, Victor Sampebulu \\ Departemen Teknik Arsitektur, Fakultas Teknik, Universitas Hasanuddin \\ Jl. Poros Malino km.6, Bontomarannu, Kabupaten Gowa, Sulawesi Selatan 92171 \\ *Email: wafxtermania@gmail.com
}

DOI: 10.25042/jpe.052019.xx

\begin{abstract}
Abstrak
Pangrampak sebagai simbol berupa ruang tentu memiliki suatu makna dalam aristektur toraja. Makna merupakan alat untuk memahami dan mengartikan lambang atau simbol, dimana makna dapat terungkap secara verbal melalui bahasa dan nonverbal melalui benda atau tanda. Makna adalah salah satu unsur yang terdapat dalam Arsitektur Nusantara yang berisi pesan dari sebuah hasil karya arsitektur. Penelitian tentang makna dapat dipelajari berdasarkan dari pengalaman dan pemahaman seseorang tentang ruang dan tempat. Tujuan penelitian ini untuk memperoleh makna Pangrampak sebagai bagian dari Arsitektur Toraja melalui peran dan fungsinya dalam kehidupan keseharian, maupun dalam adat-istiadat Masyarakat Toraja. Penelitian ini menggunakan metode penelitian Kualitatif dengan pendekatan fenomenologi, dimulai dengan pengambilan data awal dilanjutkan dengan observasi lapangan serta konfirmasi data dengan kenyataan di lapangan, kemudian mereduksi data, menyajikan data, dan mengambil kesimpulan. Hasil penelitian menunjukkan Pangrampak memiliki dua makna. Makna Pangrampak dalam Keseharian (Informal) Pangrampak merupakan ruang komunal tempat interaksi sosial rumpun keluarga dengan masyarakat luas yang berfungsi sebagai tempat melaksanakan berbagai kegiatan pengembangan kehidupan masyarakat. Makna Pangrampak dalam adat-istiadat (Formal) yaitu merupakan ruang sakral yang menjadi tempat pelaksanaan berbagai prosesi dalam suatu ritual upacara adat.
\end{abstract}

\begin{abstract}
The Meaning of Pangrampak Space in Architechture of Toraja. Pangrampak as a symbol in the form of space certainly has a meaning in the toraja architecture. Meaning is a tool to understand and interpret sign or symbols, where meaning can be expressed verbally through language and non-verbal through objects or signs. Meaning is one of the elements contained in Nusantara Architecture which contains a message from an architectural work. Research on meaning can be learned based on one's experience and understanding of space and place. The purpose of this study is to obtain the meaning of Pangrampak as part of Toraja Architecture through its role and function in daily life, as well as in the customs of the Toraja people. This study uses a qualitative research method with a phenomenological approach, starting with initial data retrieval followed by field observations and confirmation of data with reality in the field, then reducing data, presenting data, and drawing conclusions. The results showed Pangrampak has two meanings. The meaning of Pangrampak in Daily Life (Informal) is a communal space that functions as a place for social family activities and interactions with the wider community. The meaning of Pangrampak in customs (Formal) is a sacred space which is the place for carrying out various processions in a traditional ceremonial ritual.
\end{abstract}

Kata Kunci: Makna Arsitektur, Pangrampak, Tongkonan, Toraja

\section{Pendahuluan}

Tongkonan sendiri merupakan Bangunan yang sifatnya multifungsi selain sebagai tempat tinggal, Tongkonan juga merupakan pusat aktivitas dalam berbagai prosesi upacara adat di Toraja. Oleh karena itu Tongkonan merupakan salah satu titik sentral dalam pembahasan mengenai perkembangan budaya dalam kehidupan Suku Toraja dari generasi ke generasi.
Tongkonan berasal dari kata Tongkon dan Ongan. Tongkon yang berarti duduk dan Ongan yang berarti tempat bernaung [1]. Dalam hal ini, tempat untuk duduk, mendengar, membicarakan, dan menyelesaikan masalah yang penting yang berpotensi mengganggu kehidupan masyarakat di dalam wilayah adat Tongkonan tersebut., termasuk penyusunan aturan dan ketentuan adat yang dibutuhkan dalam mengatur masyarakat. Tongkonan Berasal dari kata Tongkon yang artinya duduk. Tongkonan adalah tempat duduk, 
yang artinya duduk mendengarkan perintah dan duduk mendengar penerangan serta duduk menyelesaikan persoalan-persoalan [2].

Kehadiran Tongkonan tidak dapat dipisahkan dengan Alang (lumbung padi). Berdasarkan filosofi Suku Toraja, Tongkonan adalah Ibu dan Alang adalah bapak, sehingga kehadiran kedua bangunan tersebut tidak dapat dipisahkan satu sama lain. Kata Tongkonan dapat mewakili dua makna yang berbeda, yang pertama yakni kata Tongkonan yang merujuk pada bangunan rumah tradisional suku toraja, dan yang kedua adalah kata Tongkonan sebagai suatu kawasan/lingkungan/kompleks rumah tinggal suku toraja, yang terdiri dari rumah Tongkonan (Rumah Tinggal), Pangrampak (Ruang Terbuka), Alang (Lumbung Padi).

Pangrampak adalah ruang demarkasi atau ruang pembatas antara ruang yang bersifat publik dan ruang yang bersifat privat. Ruang publik diperuntukkan bagi masyarakat umum, seperti tamu undangan, kerabat bukan keluarga, aparat pemerintah, pemuka agama, pemuka adat, dan sebagainya. Sedangkan ruang privat diperuntukkan bagi keluarga dekat-jauh [3]. Ruang publik yang dimaksud disini adalah Alang, sedangkan ruang privat yang dimaksud disini adalah Tongkonan. Dalam kehidupan sehari-hari Pangrampak berfungsi sebagai tempat bekerja, menjemur padi, dan tempat bermain anak-anak. Sedangkan pada saat ritual upacara adat, Pangrampak menjadi tempat pelaksanaan ritual upacara adat Rambu Solo' (Kedukaan) dan Rambu Tuka' (Syukuran/Hajatan).

Pangrampak sebagai ruang terbuka bersifat multifungsi baik dalam keseharian maupun sebagai prosesi Ritual Upacara Adat, seperti Rambu Tuka' (Hajatan/Syukuran) dan Rambu Solo' (Dukacita). Dengan demikian Pangrampak merupakan sebuah Ruang Publik, yang hanya diperuntukkan bagi suatu komunitas/kelompok masyarakat tertentu, atau yang disebut Ruang Komunal. Penelitian ini bertujuan untuk memperoleh makna Pangrampak sebagai bagian dari Arsitektur Toraja melalui peran dan fungsinya dalam kehidupan keseharian, maupun dalam adat-istiadat Masyarakat Toraja.

Objek penelitian yang diambil berada di Kabupaten Toraja Utara dengan pemilihan beberapa titik Tongkonan, yaitu Tongkonan Rante Limbong, dan Tongkonan Pong Munda' di Kecamatan Tallunglipu, serta Tongkonan Punti Mendila, dan Tongkonan Pata'nangka' di Kecamatan Sa'dan. Adapun beberapa alasan mengapa peneliti mengambil lokasi ini, yaitu :

1. Letaknya yang berada tepat di pusat Kota Rantepao.

2. Berada di wilayah adat dan letak geografis yang berbeda, namun memiliki keseragaman.

3. Tongkonan telah berumur lebih dari satu abad.

4. Lokasi Tongkonan yang cukup strategis, yakni berada di tepi jalan raya.

Hingga saat ini penelitian mengenai Arsitektur Toraja, dalam hal ini Tongkonan dan Alang sudah cukup banyak dapat kita temukan. Namun penelitian mengenai Ruang Pangrampak belum pernah dilakukan, padahal Pangrampak merupakan bagian yang tidak terpisahkan dari suatu Tongkonan.

\section{Metode Penelitian}

Metode yang digunakan pada penelitian ini yaitu metode Fenomenologi. Fenomenologi merupakan suatu pemikiran yang tidak hanya memandang segala sesuatu dari luarnya saja tetapi berusaha untuk menggali makna apa yang ada dibalik gejala itu [4]. Peneliti dalam pandangan fenomenologis berusaha memahami arti persitiwa dan kaitan-kaitannya terhadap orang-orang yang berada dalam situasi-situasi tertentu. Metode fenomenologi berusaha menggambarkan makna dari pengalaman hidup beberapa individu mengenai konsep fenomena yang dialaminya dan berusaha mempelajari struktur kesadaran dalam pengalaman individu [5]. Berdasarkan pengertian diatas, peneliti bermaksud mendapatkan semua informasi mengenai Pangrampak, dengan cara berinteraksi secara langsung dengan informan yaitu masyarakat Toraja yang kemudian digunakan dalam menganalisis fenomena yang terjadi. Metode pengumpulan data yang digunakan adalah observasi, wawancara, dokumentasi, studi kepustakaan. Jenis data penelitian adalah kualitatif, data yang dinyatakan dalam kata-kata, kalimat, narasi, uraian dan berbagai bentuk pemahaman lainnya. 


\section{Hasil dan Pembahasan}

\subsection{Deskripsi sampel penelitian}

Teknik pemilihan lokasi sampling adalah teknik Purposive sampling adalah teknik pengambilan sampel untuk tujuan tertentu. Lokasi sampling yakni beberapa titik Tongkonan yang berada di Kabupaten Toraja Utara, antara lain Tongkonan Rante Limbong dan Tongkonan Pong Munda' di Kecamatan Tallunglipu, serta Tongkonan Punti Mendila dan Tongkonan Pata'nangka' di Kecamatan Sa'dan.

\subsection{Deskripsi sampel penelitian}

Penentuan pembangunan suatu Tongkonan sama saja dengan memulai suatu peradaban baru. Oleh karena itu sebelum memulai proses penetuan lokasi, pada zaman dahulu masyarakat Toraja memilah-milah lokasi untuk pembangunan Tongkonan sembari menunggu Ilham dari Sang Pencipta dan Roh Leluhur, agar ditunjukkan lokasi untuk pembangunan Tongkonan sebagai tempat permukiman yang baru bagi suatu rumpun keluarga [6].

Tata letak Tongkonan membentuk jalur menurut pola timur-barat. Jadi dasar perkampungan adat mengikuti orientasi pola Mataallo-Matampu' (Timur-Barat) dengan pengaturan Tongkonan dan Alang yang saling berhadapan. Tata letak Tongkonan bersumber dari ajaran Aluk Todolo, dimana perkampungan secara konsepsional senantiasa mengikuti empat penjuru mata angin (Utara-Selatan dan Timur-Barat), kemudian Tongkonan secara konsepsional pula mengikuti model perkampungan yaitu segi empat [7].
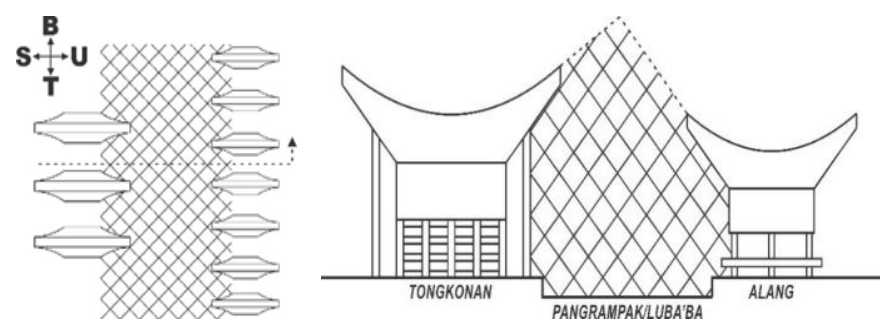

Gambar 1. Ilustrasi tongkonan

Pola penataan Tongkonan-Pangrampak-Alang didasarkan dari Banua Tongkonan. Tongkonan memiliki tiga ruangan, yaitu Tangdo (Utara), Sali (Tengah), dan Sumbung (Selatan). Tangdo sebagai ruangan untuk laki-laki, Sali sebagai ruangan untuk berkegiatan, dan Sumbung sebagai ruangan untuk perempuan. Jika diproyeksikan secara makro menjadi Tongkonan-Pangrampak-Alang, maka sejalan dengan pemahan bahwa Tongkonan sebagai Ibu, dan Alang sebagai Ayah. Begitu pula dengan Sali yang merupakan Ruang Kegiatan di dalam Rumah Tongkonan dan Pangrampak yang merupakan Ruang Kegiatan dalam suatu Tongkonan [8].

\subsection{Pelaku, Jenis, dan Daftar Kegiatan}

Peneliti membagi pelaku kegiatan menjadi dua kategori, yaitu keluarga (orang yang tinggal di Tongkonan), dan Tamu (orang tidak tinggal di Tongkonan). Kegiatan yang paling dominan adalah kegiatan sosial. Peneliti membagi Kegiatan sosial tersebut kedalam dua kegiatan, yaitu kegiatan keseharian (Informal) dan kegiatan Adat-istiadat/Ritual Upacara Adat (Formal). Kegiatan Adat-istiadat/Ritual Upacara Adat yang dimaksud disini adalah Aluk Rambu Solo' (Ritual Upacara Adat Kematian) dan Aluk Rambu Tuka' (Hajatan/Syukuran).

- Kegiatan Keseharian (Informal)

Kegiatan Informal adalah Kegiatan yang dilakukan setiap hari, mulai dari pagi hari sampai malam hari. Berikut ini adalah daftar Kegiatan keseharian.

Tabel 1. Kegiatan informal di pangrampak

\begin{tabular}{|c|c|c|}
\hline No & Kegiatan & Waktu \\
\hline 1 & Mengurus hewan ternak & \multirow[b]{2}{*}{$\begin{array}{c}\text { Pagi Hari } \\
(05.00-12.00)\end{array}$} \\
\hline 2 & $\begin{array}{l}\text { menaruh barang/material untuk } \\
\text { sementara waktu }\end{array}$ & \\
\hline 3 & Memarkir kendaraan & \multirow{3}{*}{$\begin{array}{c}\text { Siang Hari } \\
(12.00-18.00)\end{array}$} \\
\hline 4 & Bersosialisasi & \\
\hline 5 & Bermain & \\
\hline 6 & - & $\begin{array}{c}\text { Malam Hari } \\
(18.00-22.00)\end{array}$ \\
\hline
\end{tabular}


Tabel 2. Kegiatan informal di pangrampak pada tongkonan rante limbong dan tongkonan pong munda', kecamatan tallunglipu, kabupaten toraja utara

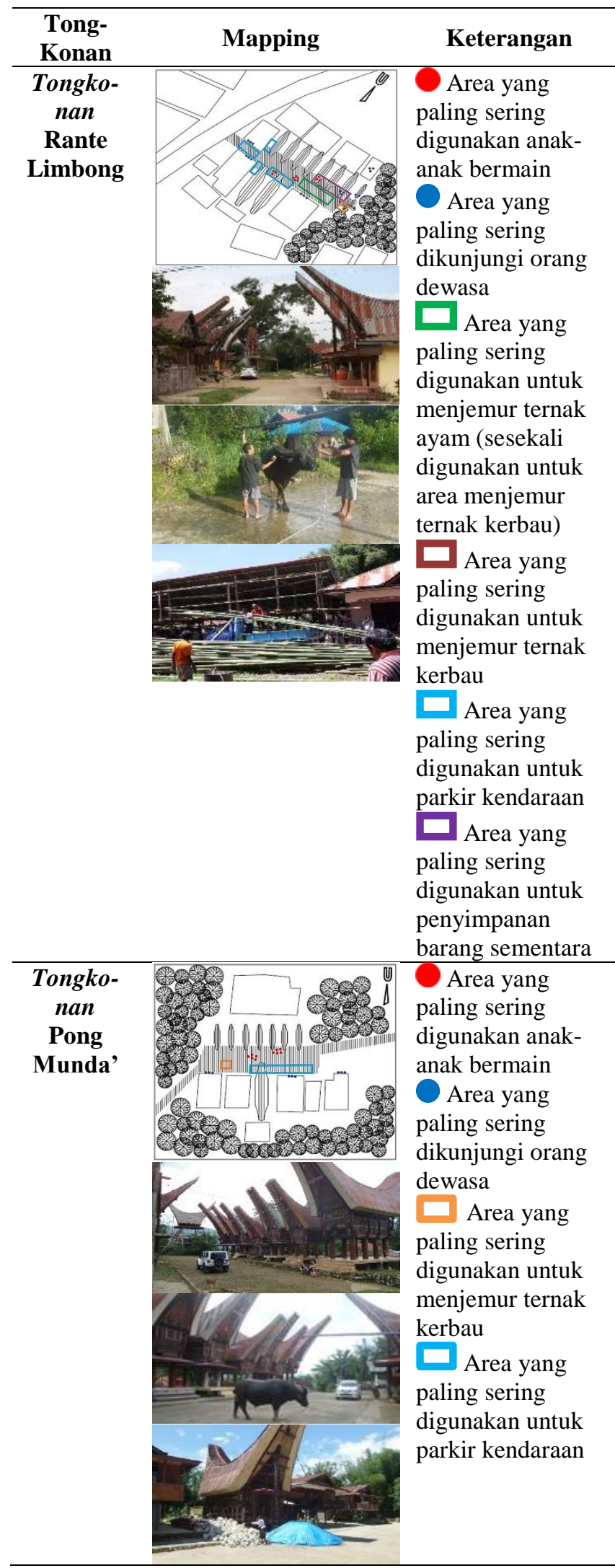

Berdasarkan Mapping untuk Kegiatan informal di atas, Pangrampak sering digunakan oleh anak-anak untuk bermain. Hal ini dikarenakan himbauan dari orang tua sehingga mudah dipantau oleh orang tua dan berada jauh dari jalan raya. Sedangkan orang dewasa memanfaatkan Pangrampak untuk mengurus hewan ternak, tempat parkir kendaraan, dan penyimpanan barang/material bangunan untuk sementara waktu.

- Kegiatan Adat-istiadat (Formal)

Kegiatan Formal adalah Kegiatan yang dilakukan pada saat dilangsungkannya Kegiatan yang berkaitan dengan upacara adat. Berikut ini adalah daftar Kegiatan saat pacara Adat-Istiadat.

- Aluk Rambu Solo' (Ritual Upacara Adat Kematian)

Istilah Aluk Rambu Solo' terbangun dari tiga kata, yaitu Aluk (keyakinan), Rambu (asap atau sinar), dan Solo' (turun). Dengan demikian, Aluk Rambu Solo' dapat diartikan sebagai upacara yang dilaksanakan pada waktu sinar matahari mulai turun (terbenam). Sebutan lain untuk upacara ini adalah aluk Rampe Matampu'. Aluk artinya keyakinan atau aturan, Rampe artinya sebelah atau bagian, dan Matampu' artinya barat. Jadi, Makna Aluk Rampe Matampu' adalah upacara yang dilaksanakan di sebelah barat dari rumah atau Tongkonan [2].

Tabel 2. Kegiatan formal rambu solo' (upacara adat kematian) di pangrampak

\begin{tabular}{cll}
\hline No. & Kegiatan & $\begin{array}{l}\text { Waktu dan } \\
\text { Keterangan }\end{array}$ \\
\hline 1 & Ma'parokko Alang & Pagi-Siang \\
& & $10.00-14.00$ \\
& & $(1-2$ Hari \\
& Sebelumnya, \\
& & Memindahkan \\
& & jenazah dari \\
& & Banua \\
& & Tongkonan ke \\
& & Alang) \\
& & \\
\hline 2 & Ma'pasa' Tedong & Pagi-Siang \\
& Tongkonan Rante Limbong & $10.00-16.00$ \\
& (Hari ke-1, \\
& Mengumpulk \\
& an Kerbau \\
& yang akan \\
\hline
\end{tabular}




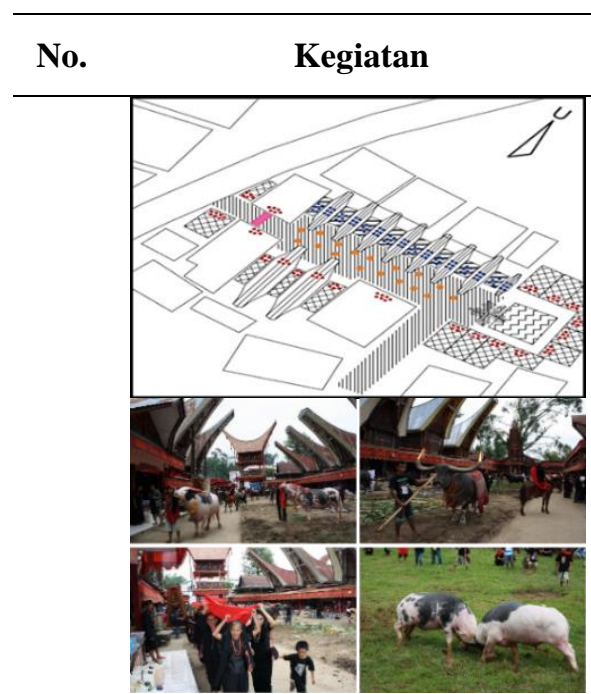

Tongkonan Pong Munda'

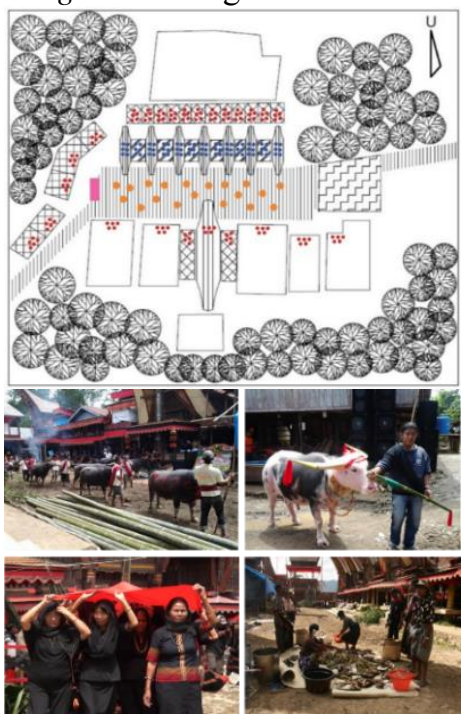

(tidak

permanen).

2 Ruang

Tamu untuk

menjamu

rombongan

tamu yang

datang untuk

menghadiri

Upacara Adat

Pemakaman

(tidak

permanen).

\begin{tabular}{lll} 
Ma'palao & Pagi-Siang \\
Tongkonan Rante Limbong & $10.00-14.00$ \\
& (Hari ke-2, \\
& Mengarak \\
& jenazah \\
& keluar dari \\
& Tongkonan \\
& sesuai rute \\
& yang telah \\
\hline
\end{tabular}

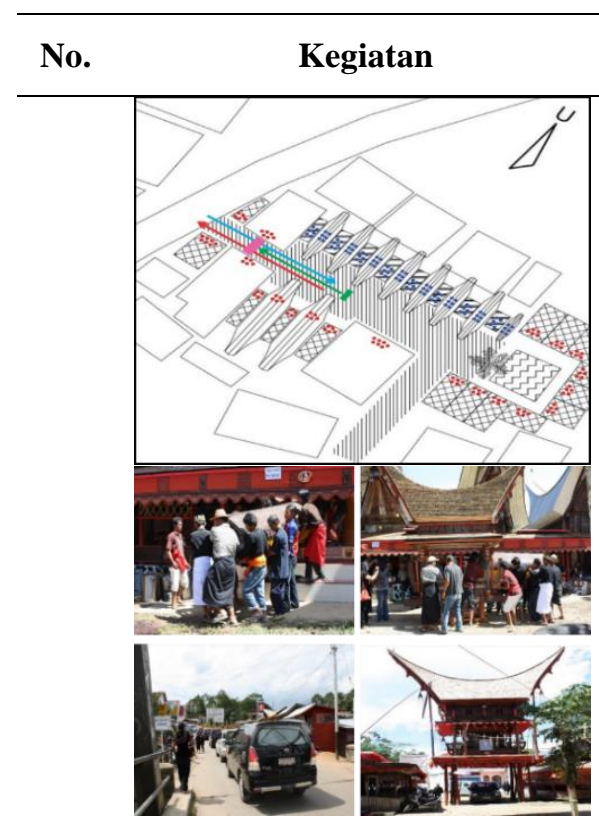

Tongkonan Pong Munda'
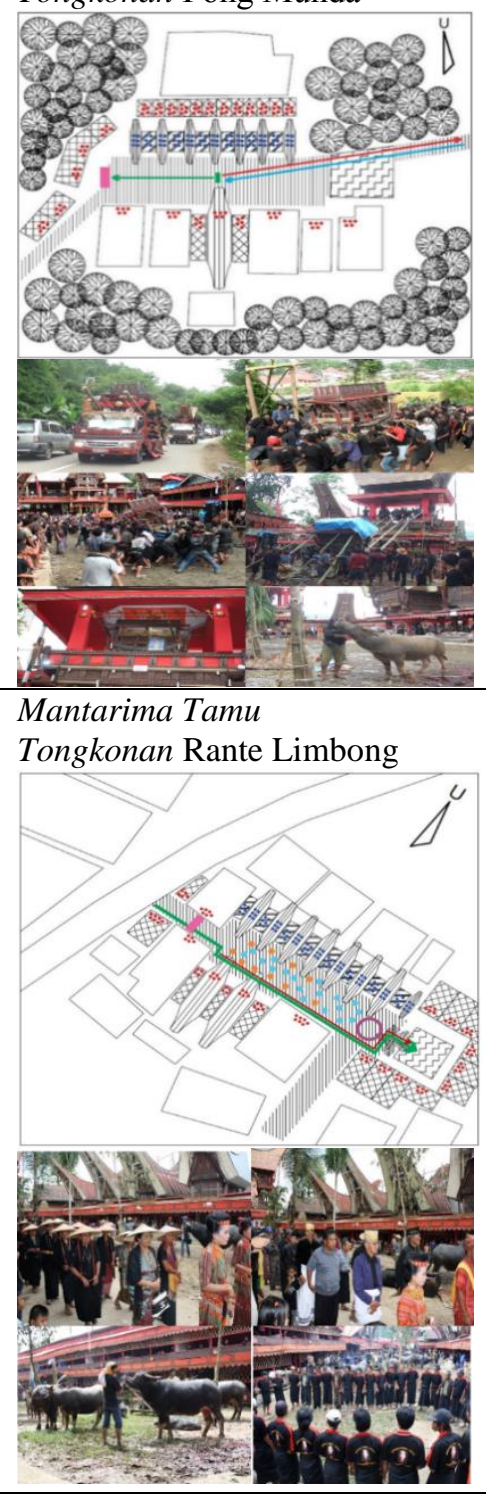

Pagi-Siang

09.00-15.00

(Hari ke-3,

Menerima

dan melayani

tamu yang

membawa

hewan kurban

Kerbau atau

Babi yang

datang ke

Upacara adat

Pemakaman)

Keterangan:

Kerbau

(Oranye) dan

Babi (Biru

Muda) yang

dibawa ke

Upacara Adat 


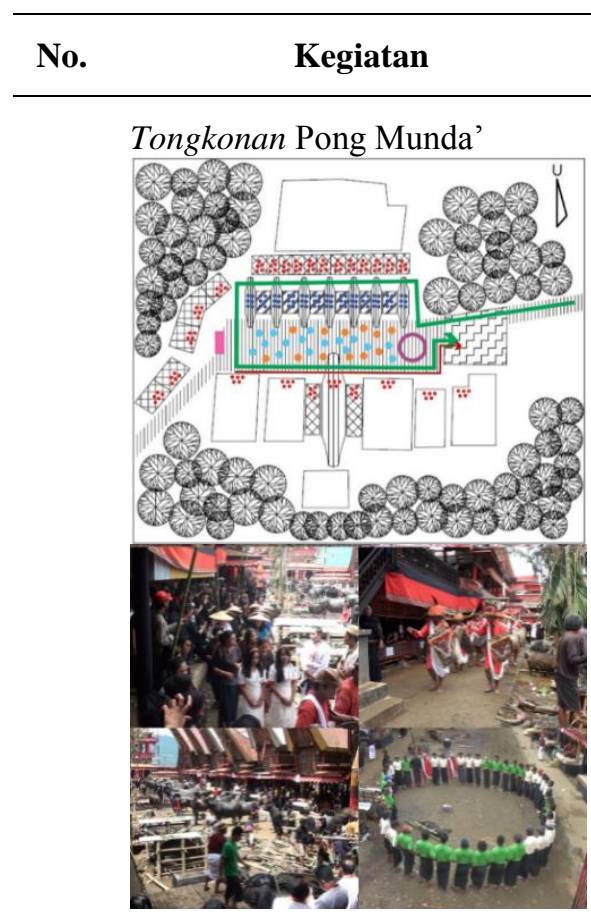

$5 \quad$ Mantunu Tedong

Tongkonan Rante Limbong

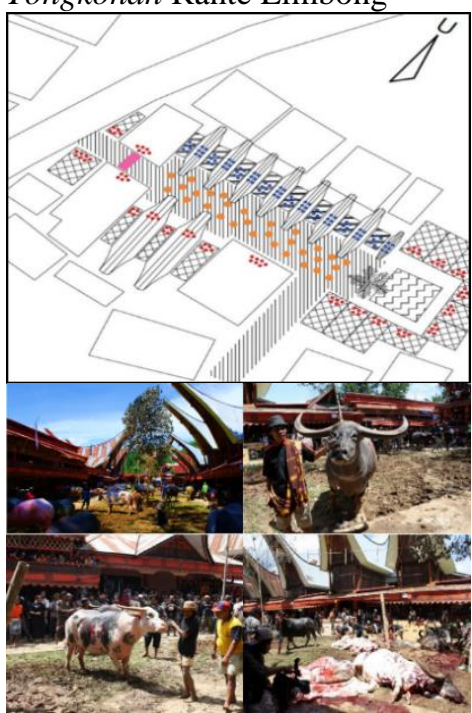

Tongkonan Pong Munda'

\begin{tabular}{c} 
Waktu dan \\
Keterangan \\
\hline
\end{tabular}

Rambu Solo'

oleh

rombongan

tamu

- Area

tempat orang-

orang

berkumpul

untuk

melakukan

tarian

Ma'Badong

$\Rightarrow$ Jalur

sirkulasi

rombongan

tamu yang

baru datang

menuju ke

Ruang Tamu

$\Rightarrow$ Jalur

sirkulasi

rombongan

keluarga yang

akan

menjamu

rombongan

tamu yang

baru datang

Pagi-Siang

13.00-17.00

(Hari

Menyesuai-

kan),

Menyembelih

Kerbau

dikurbankan

pada Upacara

Adat

Pemakaman)

Keterangan:

Kerbau

yang

dikurbankan

untuk prosesi

Upacara Adat

Kematian.

Lakkian,

menara

tempat

menaruh peti

jenazah (tidak permanen).

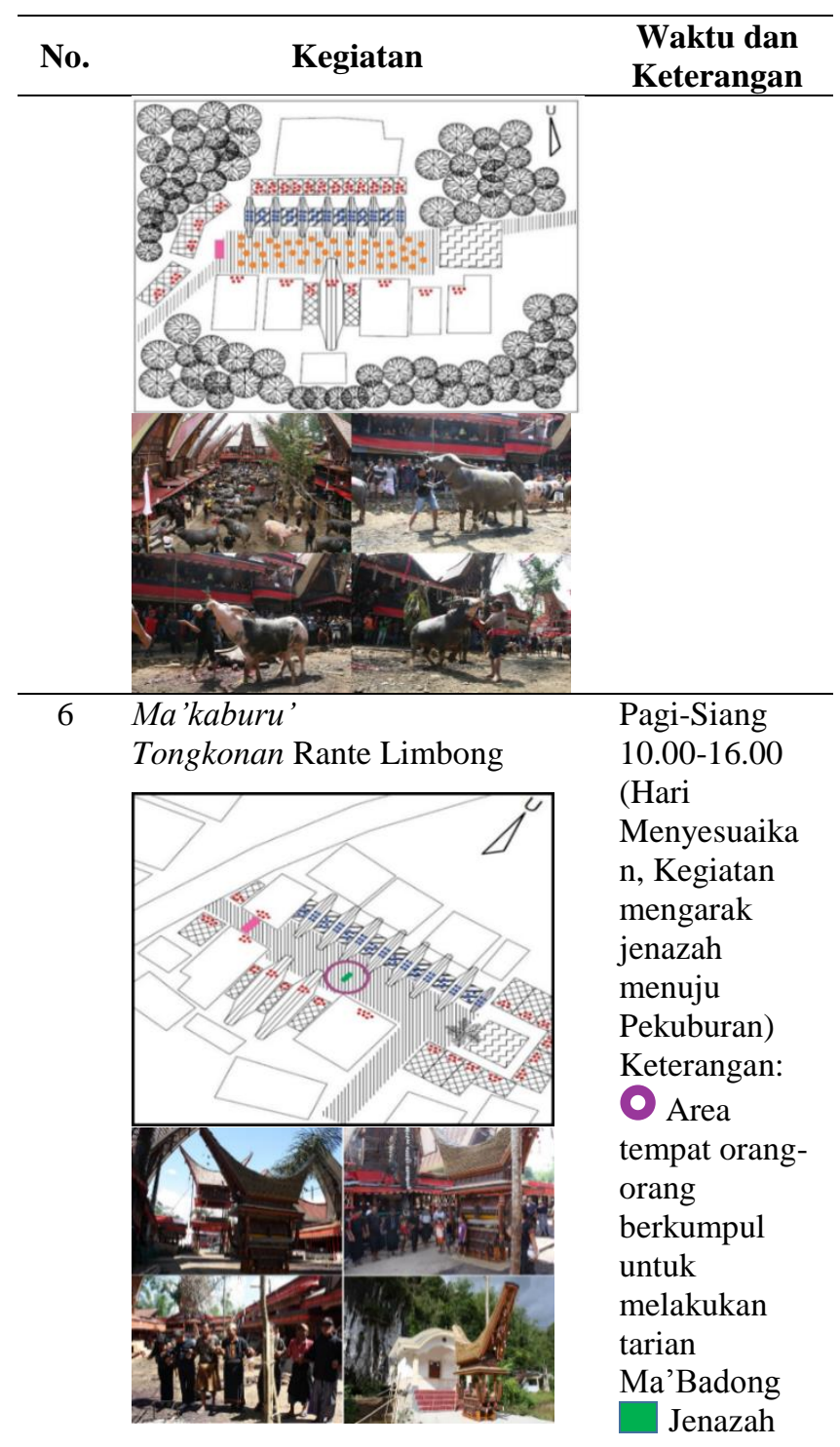

Tongkonan Pong Munda'

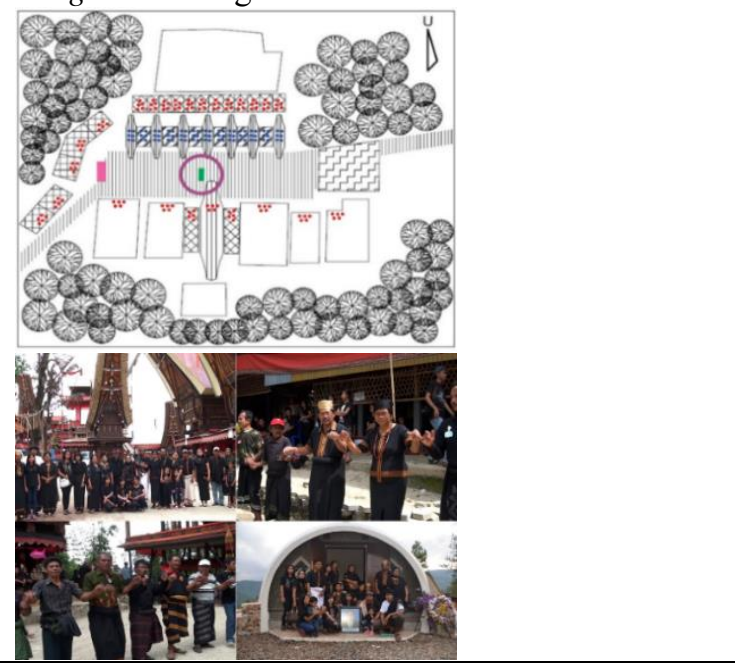

Berdasarkan Mapping untuk Kegiatan formal di atas, Pangrampak menjadi ruang yang hanya digunakan untuk ritual upacara adat. Pada saat 
ritual upacara adat berlangsung, kendaraan tidak diperkenankan memasuki Pangrampak. Pada kegiatan Rambu Solo' di atas, objek utama yaitu Jenazah yang berada di Lakkian berada di sebelah Barat Banua Tongkonan. Hal ini sejalan dengan penjelasan Sampebulu', bahwa keluarga melakukan ritual Rambu Solo' bagi leluhur yang telah meninggal untuk mengganti statusnya menjadi Todolo yang bersemayam di Puya yang berada di sebelah barat Tongkonan. Puang Matua (Sang Pencipta), Deata-deata (Dewa-dewa), dan Todolo (Roh Leluhur) dipercaya melindungi manusia yang hidup dalam dunia.

- Aluk Rambu Tuka' (Hajatan/Syukuran)

Rambu Tuka' adalah kata dalam Bahasa Toraja yang secara harafiah berarti asap yang naik atau arahnya ke atas, artinya asap persembahan itu naik ke langit sebelum matahari mencapai zenit. Rambu Tuka' sering juga disebut aluk rampe matallo, ritus-ritus di sebelah timur. Persembahan-persembahan tersebut dialamatkan kepada para dewa dan kepada para leluhur yang sudah menjadi dewa, yang sekarang dipercaya mendiami langit sebelah timur laut. Ritus-ritus dalam Rambu Tuka' dimaknai sebagai sebuah bentuk permohonan untuk mendapatkan berkat dan segala kebutuhan hidup di dunia ini [9]. Salah satu yang termasuk dalam Upacara Rambu Tuka' adalah Mangrara banua/Merok (Syukuran/Hajatan telah selesai membangun atau merenovasi Banua Tongkonan).

Tabel 3. Kegiatan formal rambu tuka' (syukuran/hajatan) di pangrampak

\begin{tabular}{cl}
\hline \multicolumn{1}{c}{ Kegiatan } & $\begin{array}{l}\text { Waktu dan } \\
\text { Keterangan }\end{array}$ \\
\hline Sore Hari \\
Ma'patama Gandang & $15.00-17.00$ \\
& $(1$ Bulan-1 \\
& Minggu \\
Sebelum & Acara, \\
& Memasukkan \\
gendang ke \\
Pangrampak \\
untuk latihan \\
Menari \\
menjelang \\
Ritual \\
Upacara \\
Adat)
\end{tabular}
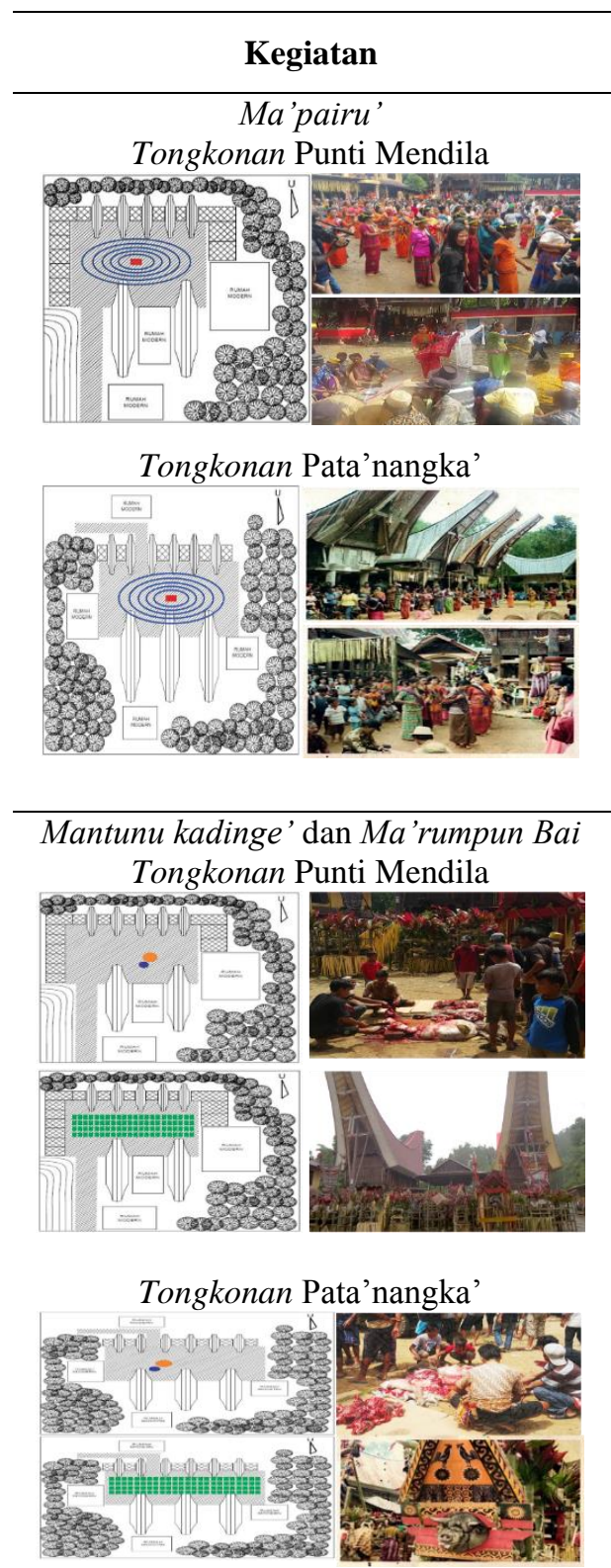

Waktu dan Keterangan

Pagi-Sore 07.00-15.00

(Hari ke-1,

Kegiatan

Tari-tarian

sebagai

wujud

sukacita

Keluarga

besar)

Keterangan:

- Para

perempuan

penari

Gendang

untuk

mengiringi

penari

Pagi-Siang

07.00-14.00

(Hari ke-2,

Menyembelih

seekor kerbau

muda yang

dikurbankan

pada saat

Ritual

Upacara Adat

dan

mempersiapk

an babi yang

akan

dikurbankan

pada saat

Ritual

Upacara

Adat)

Keterangan:

Kadinge'/

Kerbau muda

yang

dipersiapkan

untuk prosesi

Upacara Adat

Orang

yang

menyembelih

Kadinge'

Lempol

Lettoan,

kandang babi

Mantunu bai/Bambangan Lempo

Tongkonan Punti Mendila

Pagi-Siang

07.00-14.00

(Hari ke-3, 


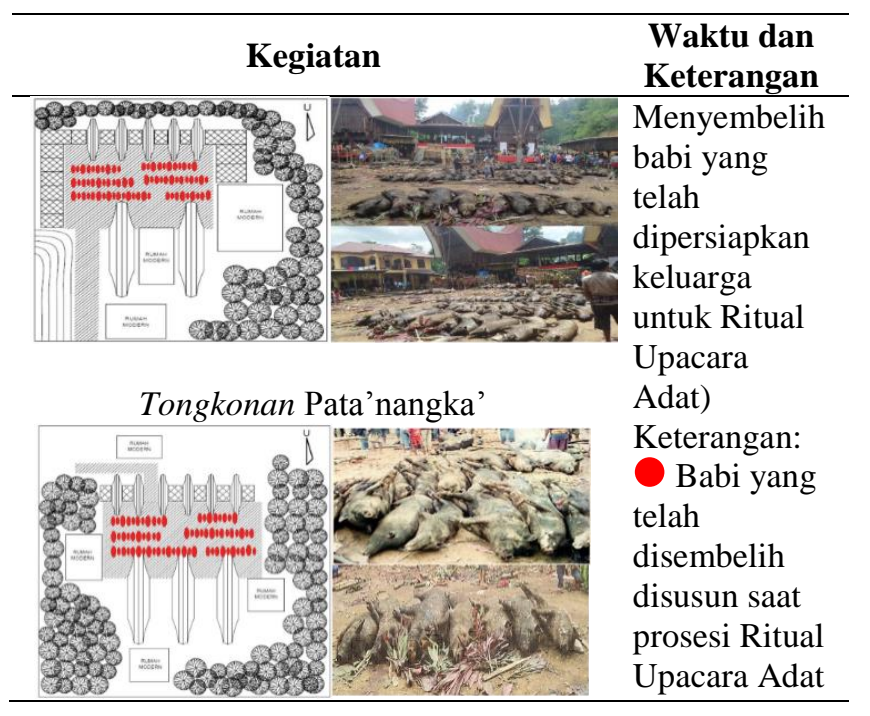

Salah satu yang termasuk dalam Upacara Rambu Tuka' adalah Mangrara banua/Merok (Syukuran/Hajatan telah selesai membangun atau merenovasi Banua Tongkonan). Pada kegiatan Rambu Tuka' di atas, objek utama yaitu Kadinge'/Kerbau muda yang disembelih di sebelah Timur Banua Tongkonan yang melaksanakan Syukuran/Hajatan sebagai persembahan kepada Deata (Dewa-dewa) sebagai satu dari tiga pelindung yang dipercaya melindungi manusia yang hidup dalam dunia.

\subsection{Dampak Pangrampak}

Dengan adanya Pangrampak sebagai ruang komunal tentu ada dampak yang ditimbulkan. Berdasarkan pengamatan peneliti di lapangan, terdapat dampak dalam hal Arsitektur, Sosial, dan Ekonomi.

Tabel 4. Dampak pangrampak dalam kehidupan masyarakat toraja

\begin{tabular}{|c|c|c|}
\hline $\begin{array}{c}\text { Dampak } \\
\text { Keseharian } \\
\text { (Informal) } \\
\end{array}$ & Aspek & $\begin{array}{c}\text { Dampak Adat- } \\
\text { Istiadat } \\
\text { (Formal) }\end{array}$ \\
\hline $\begin{array}{l}\text { Ruang terbuka } \\
\text { hijau dalam } \\
\text { suatu } \\
\text { pemukiman } \\
\end{array}$ & & $\begin{array}{l}\text { Ruang terbuka } \\
\text { multifungsi dalam } \\
\text { suatu pemukiman }\end{array}$ \\
\hline $\begin{array}{l}\text { Tersedia ruang } \\
\text { terbuka yang } \\
\text { dapat } \\
\text { digunakan } \\
\text { bersama }\end{array}$ & Arsitektur & $\begin{array}{l}\text { Ruang terbuka } \\
\text { yang } \\
\text { memungkinkan } \\
\text { penambahan } \\
\text { massa bangunan } \\
\text { untuk } \\
\text { pelaksanaan ritual } \\
\text { Upacara Adat }\end{array}$ \\
\hline
\end{tabular}

\begin{tabular}{l}
$\begin{array}{c}\text { Dampak } \\
\text { Keseharian } \\
\text { (Informal) }\end{array}$ \\
\hline Meningkatkan \\
nilai estetika \\
suatu \\
Tongkonan \\
\\
\\
\\
Jalur sirkulasi \\
manusia, hewan \\
dan kendaraan \\
yang sangat \\
leluasa
\end{tabular}

Menjadi salah satu simbol status sosial suatu Tongkonan

Sosial

Tersedia ruang untuk merawat hewan-hewan ternak

Ruang tempat dilaksanakannya bebagai Ritual Upacara Adat

sosial

Tersedia ruang digunakkan anak-anak untuk bermain, namun tetap pengawasan orang tua terbuka yang

\begin{tabular}{|c|c|c|}
\hline & $\begin{array}{l}\text { Menjadi } \\
\text { satu } \\
\text { pendukung } \\
\text { pelestarian } \\
\text { Budaya Tor }\end{array}$ & $\begin{array}{r}\text { salah } \\
\text { faktor }\end{array}$ \\
\hline & $\begin{array}{l}\text { Menjadi } \\
\text { interaksi } \\
\text { antara ke } \\
\text { dan tamu } \\
\text { hadir }\end{array}$ & $\begin{array}{r}\text { tempat } \\
\text { sosial } \\
\text { eluarga } \\
\text { yang }\end{array}$ \\
\hline & $\begin{array}{l}\text { Memperera } \\
\text { persaudaraa } \\
\text { dalam } \\
\text { keluarga }\end{array}$ & $\begin{array}{l}\text { t tali } \\
\text { an } \\
\text { umpun }\end{array}$ \\
\hline & $\begin{array}{l}\text { Menjadi } \\
\text { satu } \\
\text { pendukung } \\
\text { perputaran } \\
\text { yang men } \\
\text { karena tra }\end{array}$ & $\begin{array}{r}\text { salah } \\
\text { faktor } \\
\text { uang } \\
\text { ingkat } \\
\text { ansaksi } \\
\end{array}$ \\
\hline
\end{tabular}




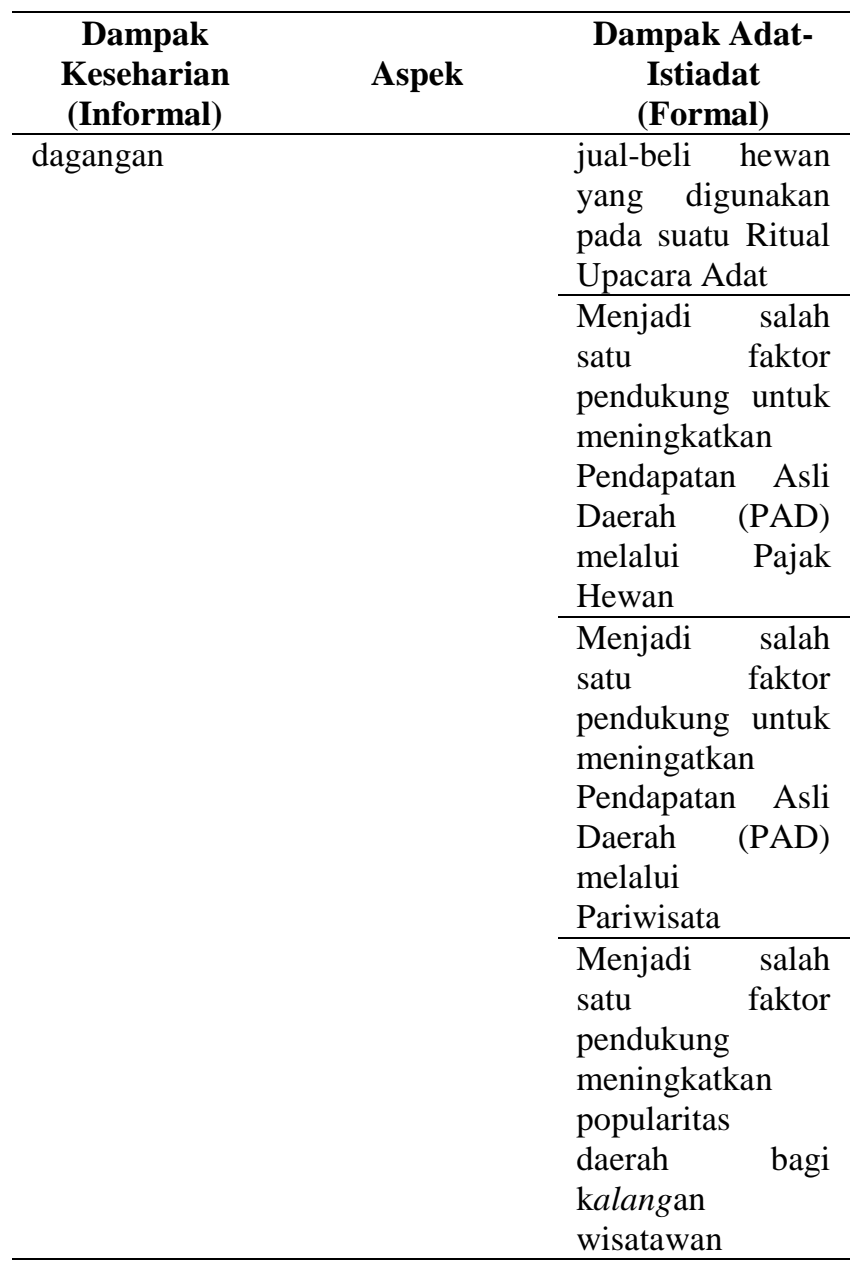

3.5. Hubungan Pangrampak dengan Teori Makna dan Arsitektur Vernakular

Menurut Turan Meter Dalam Mentayani, Ikaputra, dan Muthia (2017) [10], Arsitektur vernakular adalah arsitektur yang tumbuh dan berkembang dari arsitektur rakyat yang lahir dari masyarakat etnik dan berakar pada tradisi etnik, serta dibangun oleh tukang berdasarkan pengalaman (trial and error), menggunakan teknik dan material lokal serta merupakan jawaban atas setting lingkungan tempat bangunan tersebut berada dan selalu membuka untuk terjadinya transformasi.

Makna merupakan alat untuk melihat, memahami dan mengartikan lambang atau simbol, dimana makna dapat terungkap secara verbal (bahasa) atau melalui kata-kata dan nonverbal melalui benda atau tanda. Unsur makna sebagai pesan yang ingin disampaikan dan simbol sebagai media fisiknya [10].

Arsitektur vernakular memiliki dua ranah dan unsur, yaitu: Bentuk dan Makna. Unsur Bentuk berada dalam ranah Fisik, sedangkan unsur Makna berada dalam ranah Abstrak. Baik unsur Bentuk maupun unsur Makna, masing-masing memiliki 3 (tiga) aspek vernakularitas, yaitu: Teknis, Budaya, dan Lingkungan [10].

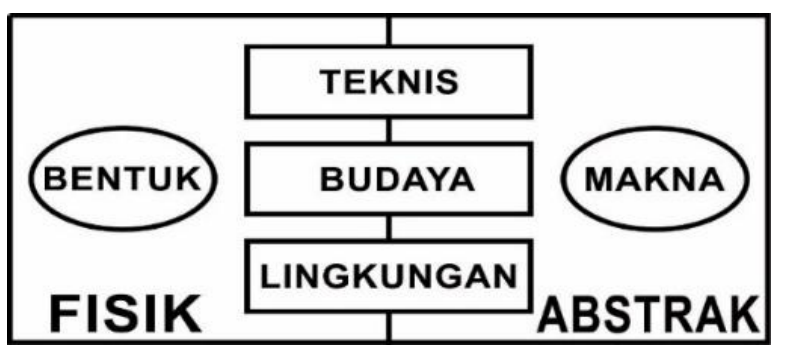

Gambar 2. Aspek-aspek vernakularitas: aspek teknis, aspek budaya, dan aspek lingkungan, pada kedua ranah dan unsur

(Sumber: Mentayani dan Ikaputra, 2011)

Aspek teknis pada Pangrampak dalam hal ini mengenai proses terbentuknya ruang Pangrampak melalui pola tata massa yang bersumber dari ajaran Aluk Todolo antara Banua Tongkonan dan Alang sebagai pembatasnya. Aspek Budaya pada Pangrampak menyangkut tempat pelaksanaan berbagai prosesi kegiatan Adat-istiadat, merupakan milik bersama dan menjadi tanggung jawab bersama segenap anggota rumpun keluarga dalam Tongkonan tersebut. Aspek Lingkungan pada Pangrampak dalam hal ini sebagai ruang terbuka dalam Tongkonan yang mendukung berbagai kegiatan pengembangan kehidupan masyarakat Toraja yang sebagian besar bekerja di sektor pertanian dan peternakan.

\subsection{Hubungan Pangrampak dengan Teori Ruang dan Tempat}

Ruang (Space) lebih didefinisikan sebagai sebuah hal yang abstrak, sedangkan tempat (Place) diartikan sebagai sebuah entitas unik, $a$ special ensemble, yang memiliki sejarah dan makna [11]. Dengan demikian, dalam konteks kegiatan keseharian, Pangrampak merupakan sebuah ruang, karena yang sifatnya multifungsi dan batasan yang tidak jelas sehingga kondisinya menjadi abstrak. Sedangkan dalam konteks kegiatan adat-istiadat, Pangrampak merupakan sebuah tempat yang memiliki batasan yang jelas, karena adanya penambahan massa berupa pondok-pondok yang menjadi pembatas ruang dan terdapat kondisi tertentu dalam ruang 
tersebut, dalam hal ini pelaksanaan ritual upacara adat yang memiliki sejarah dan makna dalam kehidupan masyarakat Toraja. Pangrampak mencakup sisi samping Banua Tongkonan dan sisi samping Alang akan tetapi bagian ruang Pangrampak tersebut lebih sering dijadikan jalur sirkulasi pada saat kegiatan keseharian. Pada saat kegiatan Adat-istiadat, sisi samping Banua Tongkonan dan Alang ditutup dengan mendirikan pondok-pondok yang disebut Ongan pada saat kegiatan Rambu Tuka' dan disebut Lantang pada kegiatan Rambu Solo', yang berfungsi sebagai tempat bagi Pemangku Adat, Tamu, dan Keluarga jauh [6].

\subsection{Peran, Fungsi, dan Makna Pangrampak dalam Arsitektur Toraja}

Peran Pangrampak dibagi menjadi dua, yakni peran fungsional dan peran spasial. Peran fungsional antara lain, menjadi tempat untuk melaksanakan Kegiatan keseharian untuk pengembangan kehidupan masyarakat, dan menjadi tempat pelaksanaan Ritual Upacara Adat, baik Rambu Tuka' (Hajatan) maupun Rambu Solo' (Kedukaan). Peran spasial Pangrampak adalah menjadi ruang pengikat antar massa bangunan dalam Tongkonan, menjadi ruang demarkasi yang menjaga privasi pihak keluarga dan tamu, dan menjadi pusat orientasi massa bangunan dalam Tongkonan.

Fungsi Pangrampak dalam kegiatan Keseharian (Informal) yakni merupakan ruang komunal tempat interaksi sosial rumpun keluarga dengan masyarakat luas yang juga berfungsi sebagai tempat dilaksanakan berbagai kegiatan pengembangan kehidupan masyarakat dan interaksi sosial. Dalam kegiatan Adat-istiadat (Formal) Pangrampak merupakan ruang sakral yang menjadi sentral pelaksanaan berbagai prosesi dalam suatu ritual upacara adat.

Arsitektur vernakular memiliki dua ranah dan unsur, yaitu: Bentuk dan Makna, yang keduanya memiliki tiga aspek vernakularitas, yaitu: Teknis, Budaya, dan Lingkungan. Jika ketiga aspek tersebut dijadikan acuan untuk menggali makna Pangrampak dari dua sisi, yakni kegiatan keseharian dan kegiatan adat-istiadat, maka makna Pangrampak dalam kegiatan keseharian (Informal) adalah merupakan ruang terbuka di dalam suatu Tongkonan yang bersifat ruang komunal, sehingga dapat dikondisikan sifat pemakaian, pemeliharaan, dan pengawasannya, karena merupakan milik bersama, dan Pangrampak menjadi tempat interaksi sosial serta tempat melaksanakan berbagai kegiatan pengembangan kehidupan masyarakat. Sedangkan makna Pangrampak dalam kegiatan Adat-istiadat (Formal) adalah merupakan ruang terbuka dalam suatu Tongkonan, tempat penambahan massa bangunan yang akan digunakan dalam suatu ritual upacara adat, Pangrampak menjadi sakral karena merupakan tempat dilaksanakannya semua prosesi dalam suatu ritual upacara adat yang selalu melibatkan masyarakat dalam jumlah besar dalam suatu wilayah adat.

\subsection{Pangrampak dalam Arsitektur Nusantara}

Arsitektur nusantara mengenal ruang komunal sebagai bagian dari kearifan lokal, dengan bukti konkretnya dapat terlihat pada pola ruang di berbagai rumah tradisional di Indonesia. Pangrampak sebagai bagian dari Tongkonan merupakan kearifan lokal yang menunjukkan keseragaman dengan kearifan lokal lain di wilayah nusantara dari aspek arsitektur sebagai ruang komunal. Ruang Komunal menjadi solusi bagi cara hidup masyarakat nusantara yang berpegang teguh pada prinsip gotong-royong.

\section{Kesimpulan}

Berdasarkan hasil pengolahan data maka diperoleh kesimpulan bahwa Peran Pangrampak memiliki peran fungsional dan peran spasial. Peran fungsional antara lain, menjadi tempat untuk melakukan Kegiatan keseharian untuk pengembangan kehidupan masyarakat, dan menjadi tempat pelaksanaan Ritual Upacara Adat, baik Rambu Tuka' (Hajatan) maupun Rambu Solo' (Kedukaan). Peran spasial Pangrampak adalah menjadi ruang pengikat antar massa bangunan dalam Tongkonan, menjadi ruang demarkasi yang menjaga privasi keluarga dan tamu, dan menjadi pusat orientasi massa bangunan dalam Tongkonan.

Fungsi Pangrampak dalam kegiatan Keseharian (Informal) yakni merupakan ruang komunal tempat interaksi sosial rumpun keluarga 
dengan masyarakat luas yang juga berfungsi sebagai tempat dilaksanakan berbagai kegiatan pengembangan kehidupan masyarakat dan interaksi sosial. Dalam kegiatan Adat-istiadat (Formal) Pangrampak merupakan ruang sakral yang menjadi sentral pelaksanaan berbagai prosesi dalam suatu ritual upacara adat.

Makna Pangrampak dalam kegiatan keseharian (Informal) adalah merupakan ruang terbuka di dalam suatu Tongkonan yang bersifat ruang komunal, sehingga dapat dikondisikan sifat pemakaian, pemeliharaan, dan pengawasannya, karena merupakan milik bersama, dan menjadi tempat interaksi sosial serta tempat melaksanakan berbagai kegiatan pengembangan kehidupan masyarakat. Sedangkan makna Pangrampak dalam kegiatan Adat-istiadat (Formal) adalah ruang terbuka dalam suatu Tongkonan, tempat penambahan massa bangunan untuk digunakan dalam ritual upacara adat, Pangrampak menjadi sakral karena merupakan tempat dilaksanakannya prosesi upacara adat yang melibatkan masyarakat di suatu wilayah adat.

\section{Ucapan Terimakasih}

Penelitian ini dapat dilaksanakan dengan baik berkat dukungan dari berbagai pihak. Untuk itu peneliti Mengucapkan terima kasih kepada Bapak Saharuddin, S.Sos. dan Pak Haerul Muayyar, S.Sos, selaku Staff Pascasarjana Departemen Arsitektur, Universitas Hasanuddin atas arahannya selama ini. Terima kasih juga kepada Narasumber Tomina Semuel Barumbun, Bapak Sismay Eliata Tulungallo, dan semua pihak yang telah membantu dalam penyelesaian penelitian ini.

\section{Referensi}

[1] Bararuallo, Frans. 2010. Kebudayaan Toraja. Yogyakarta: Pohon Cahaya.

[2] Tangdilintin, L.T., 1975. Tongkonan dengan Seni dan Koleksinya. Tana Toraja: YALBU.

[3] Sampebulu, Victor. 2010. The Meaning of Tongkonan in Belief and Customs of Aluk Todolo. Makassar.

[4] Wirawan. 2012. Teori-teori Sosial Dalam Tiga Paradigma. Jakarta: KENCANA.

[5] Moleong, Lexy J. 2016. Metodologi Penelitian Kualitatif Edisi Revisi. Jakarta: Remaja Rosdakarya.

[6] Barumbun, Semuel. 2018. Arsitektur Toraja. Rantepao. 90 mins.
[7] Lullunlangi, M, Sampebua'. 2003. Arsitektur Tradisional Toraja Merupakan Ekspresi Aluk Todolo, 9(3), 300-308

[8] Tulungallo, Sismay Eliata. 2019. Arsitektur Toraja dan Aluk Todolo. Rantepao. 60 mins.

[9] Kobong, Theodorus. 2008. Injil dan Tongkonan. Jakarta: BPK Gunung Mulia.

[10] Mentayani, Ikaputra, dan Muthia. 2017. Menggali Makna Arsitektur Vernakular: Ranah, Unsur, dan Aspek-Aspek Vernakularitas. Temu Ilmiah IPLBI 2017.

[11]Roihanah, Ita. 2015. Ruang Dan Tempat Urban: Antara Lokalitas Dan Universalitas. Makassar. 